\title{
Habitat differentiation, hybridization and gene flow patterns in mixed populations of diploid and autotetraploid Dactylorhiza maculata s.l. (Orchidaceae)
}

\author{
David Ståhlberg • Mikael Hedrén
}

Published online: 9 January 2008

(C) Springer Science+Business Media B.V. 2007

\section{Erratum to: Evol Ecol}

DOI 10.1007/s10682-007-9228-y

This paper should reflect 2nd author: Mikael Hedrén

Acknowledgements should have read as follows:

"We thank Ingela Ståhlberg for assistance in the field and Louise Hathaway for correcting and improving the language. We also thank two anonymous reviewers for helpful comments. Financial support was given by Anna and Svante Murbecks minnesfond and Lunds botaniska förening to DS. The project was also supported by The Swedish Research Council for Environment, Agricultural Sciences and Spatial Planning, FORMAS to MH (grant 2002-0102)."

The online version of the original article can be found under doi:10.1007/s10682-007-9228-y.

D. Ståhlberg $(\bowtie) \cdot$ M. Hedrén

Plant Ecology and Systematics, Department of Ecology, Lund University, Sölvegatan 37,

Lund 223 62, Sweden

e-mail: david.stahlberg@ekol.lu.se

M. Hedrén

e-mail: mikael.hedren@ekol.lu.se 